\title{
Prevalence and determinants of anaemia in women of reproductive age in Sudan: analysis of a cross-sectional household survey
}

Khalid Abdelmutalab Elmardi ${ }^{*}$ (D), Ishag Adam², Elfatih Mohammed Malik3 ${ }^{3}$ Tarig Abdalla Abdelrahim4, Mousab Siddig Elhag ${ }^{4}$, Abdalla Ahmed Ibrahim ${ }^{4}$, Mariam Adam Babiker ${ }^{4}$, Asma Hashim Elhassan ${ }^{5}$, Hmooda Toto Kafy ${ }^{6}$, Azza Tageldin Elshafie ${ }^{4}$, Lubna Mohammed Nawai ${ }^{4}$, Mujahid Sheikhedin Abdin ${ }^{1}$ and Stef Kremers ${ }^{7}$

\begin{abstract}
Background: Anaemia is a global health problem and women in reproductive age (WRA) are amongst the most affected population. Its consequences include low birth weight and maternal mortality. This study aimed to assess the prevalence of anaemia and to identify its determinants in Sudanese women in reproductive age.

Methods: A population-based cross-sectional study was conducted in Sudan in 2016. A multi-stage stratified cluster sampling design was executed with consideration of rural population, urban population, and internally displaced persons/refugees camps residents. All women in reproductive age (15-49years), classified by pregnancy status, in the targeted households were surveyed and personal characteristic data were collected. Their haemoglobin level and malaria infection (using rapid diagnostic test, RDT) were assessed. The World Health Organization (WHO) haemoglobin level cut-off for defining anaemia and severe anaemia in pregnant and non-pregnant women was used. Logistic regression analyses were performed.
\end{abstract}

Results: A total of 4271 women (WRA) of which 421 (9.9\%) pregnant women (PW) were included in the study. The overall anaemia prevalence in WRA was 35.6\%. It was 36.0 and $35.5 \%$ in PW and non-pregnant women (NPW), respectively. The average haemoglobin level was found to be $113.9 \mathrm{~g} / \mathrm{L}$ (SD 16.3) and 123.2 g/L (SD 15.7) for PW and NPW respectively. Severe anaemia prevalence was $1.2 \%$ in each group. In the logistic regression model, anaemia was associated with malaria infection in PW (aOR 4.100, 95\% Cl 1.523-11.039, $p=0.003$ ), NPW (aOR 2.776, $95 \% \mathrm{Cl} 1.889-4.080, p<0.001$ ), and WRA (aOR 2.885, 95\% Cl 2.021-4.119, $p<0.001$ ). Other identified determinants of anaemia in NPW was living in camps (aOR 1.499, 95\%Cl 1.115-2.017, $p=0.007$ ) and in WRA was being in the poorest economic class (aOR 1.436, 95\%Cl 1.065-1.936, $p=0.018)$.

(Continued on next page)

\footnotetext{
* Correspondence: khalid.elmardi@gmail.com

${ }^{1}$ Health Information, Monitoring and Evaluation and Evidence Department, Federal Ministry of Health, Khartoum, Sudan

Full list of author information is available at the end of the article
}

(C) The Author(s). 2020 Open Access This article is licensed under a Creative Commons Attribution 4.0 International License, which permits use, sharing, adaptation, distribution and reproduction in any medium or format, as long as you give appropriate credit to the original author(s) and the source, provide a link to the Creative Commons licence, and indicate if changes were made. The images or other third party material in this article are included in the article's Creative Commons licence, unless indicated otherwise in a credit line to the material. If material is not included in the article's Creative Commons licence and your intended use is not permitted by statutory regulation or exceeds the permitted use, you will need to obtain permission directly from the copyright holder. To view a copy of this licence, visit http://creativecommons.org/licenses/by/4.0/ The Creative Commons Public Domain Dedication waiver (http://creativecommons.org/publicdomain/zero/1.0/) applies to the data made available in this article, unless otherwise stated in a credit line to the data. 
(Continued from previous page)

Conclusions: Anaemia is a public health problem in Sudan. The study supported the association between malaria infection and anaemia, but not with low and moderate malaria transmission areas. Resources need to be allocated for all anaemic populations with special attention for the populations in most need and interventions need to be implemented based on local variations. Malaria control interventions, specifically case management, may have a major impact in reducing anaemia prevalence in low to moderate malaria transmission areas.

Keywords: Anaemia, Camps, Haemoglobin, Logistic regression, Malaria, Pregnant women, Sudan, Women in reproductive age

\section{Background}

Anaemia is a world-wide problem, but affecting more the low and middle-income countries with young children and pregnant women as the most affected population groups [1, 2]. The latest World Health Organization (WHO) report on anaemia estimated that 32.4 million pregnant women (PW) and 496.3 million non-pregnant women (NPW) worldwide were anaemic in 2011, giving a total of 528.7 million women of reproductive age (WRA). Out of those, 19.4 million NPW and 0.8 million PW were estimated as having severe anaemia, which sums up to a total of 20.2 million WRA $[1,2]$.

Causes of anaemia include blood loss, infections, acute and chronic diseases, micronutrient deficiencies, splenomegaly, and haemoglobinopathies [3, 4]. Among these, iron deficiency contributes to around $50 \%$ of the anaemia problem $[2,5]$. On top of its social and economic development impact, the effect of anaemia as a contributing factor for maternal and perinatal adverse effect is reported. Evidence has documented the association between anaemia and postpartum haemorrhage, preterm labour, low birth weight, small for gestational age babies, and perinatal death [6-8]. Iron deficiency anaemia was found to affect work productivity and hence could lead to a loss of $1.3 \%$ of the gross domestic product [9].

The magnitude of the anaemia problem is classified based on its prevalence into mild public health problem when the level of anaemia prevalence is less than $20 \%$, moderate public health problem if the prevalence is between $20 \%$ and less than $40 \%$, and severe public health problem if it is equal to or more than $40 \%$ [10]. The global community set a target of $50 \%$ reduction of anaemia in WRA by 2025 as part of the comprehensive implementation plan on maternal, infant and young child nutrition [11]. Progress towards this target needs reliable statistics and monitoring systems at the country level. In Sudan, most of the recent data regarding anaemia are based on small-scale localized studies or estimations and many of these are health facility-based. Findings from these localized studies showed huge variation in anaemia prevalence (26.2 to $80.3 \%$ ) [12-15]. Limitations of these studies stand a barrier against the country to use these figures as a base to monitor the progress. Micronutrient supplementation, promotion of dietary diversification and fortification, optimal hygiene, and infection control are among anti-anaemia interventions adopted in Sudan [16]. This study was done in Sudan to establish a national baseline figure for anaemia in WRA as well as to identify its determinants to better design interventions towards the neediest communities.

\section{Methods}

This cross-sectional study was conducted in Sudan in 2016. Sudan is a low-middle income African country with 40.852 million US\$ GDP per capita as estimated for the year 2018 [17]. The country with space of $1,882,000$ Sq. Kilometres is administratively divided into 18 states. Some areas in Darfur region, South Kordofan and Blue Nile states are affected by civil conflict and insecurity which may affect accessibility. The country has 8 camps for internally displaced persons (IDPs) and is hosting 22 refugees' camps which are located in 5 Darfurs, South Kordofan, West Kordofan, White Nile, Gedaref, and Kassala states. Refugees are mostly from countries such as Eritrea, Ethiopia and South Sudan. The total population for 2018 is 39.28 million, the life expectancy at birth is 59.8 years, and the annual growth rate is $2.8 \%$ [18]. The urban population represents $32.7 \%$ of the population, WRA are $25.7 \%$, and the average household members are five [19].

A population-based household survey to measure the prevalence of anaemia in WRA (15-49 years), disaggregated by pregnancy status, was combined with a malaria indicator survey and carried out on November 2016 just after the rainy season. A multi-stage stratified cluster sampling technique was used to select the study clusters using the number of households and population in popular administrative units (PAUs) based on the 2008 census projected to 2016. All (8) internally displaced persons (IDP) camps and 4 randomly selected refugees camps were chosen for the study. Out of the national number of clusters calculated (509 clusters), the number of camps clusters has been assigned following the size of the population resident in these camps. Then, remaining clusters have been allocated equally to states. Within states, the allocation was in proportionate to rural/urban 
population ratios. In each cluster of more than 150 households, segmentation was done. Then, in a one randomly selected segment, 20 households were randomly selected. In each household, all WRA were enrolled in the survey. All households and participants were assured of their right to participate in this study and written consent was obtained from them before enrolment. Ethical clearance for this study was obtained from the Sudan federal ministry of health, ethical and technical review board.

Data from households were collected in Arabic language using a questionnaire designed in a digital personal data assistant (PDA) device by trained health personnel. Locally developed web-based survey application with its data validation functions was used for data collection. A finger-prick capillary blood sample was taken by trained laboratory assistants from study participants for testing of haemoglobin level using field battery-operated device (HemoCue ${ }^{\bullet} 301+$ analyser from Radiometer Group) and for malaria testing using Plasmodium falciparum and Plasmodium vivax specific histidine-rich protein II malaria rapid diagnostic test (RDT) (SD BIOLINE Malaria Ag Pf/Pv $v^{\circ}$ from STANDA RD DIAGNOSTICS INC/ SD).

In this study, the WHO standard cut-off points for anaemia and severe anaemia for WRA is used [20-22]. Any PW with a haemoglobin level of less than $110 \mathrm{~g} / \mathrm{L}$ is considered anaemic and with a haemoglobin level of less than $70 \mathrm{~g} / \mathrm{L}$ is considered severely anaemic. On the other hand, any NPW with a haemoglobin level of less than $120 \mathrm{~g} / \mathrm{L}$ was classified as having anaemia and $<80 \mathrm{~g} / \mathrm{L}$ was classified as having severe anaemia. Anaemia in PW and NPW as per each group definition is combined to give the overall anaemia in WRA. The same was applied for severe anaemia.

Malaria infection is considered in the study when malaria parasite is identified in the study population using malaria rapid diagnostic test. Study participants who were found to be positive for malaria were treated according to the standard treatment guidelines while anaemic individuals were referred to the nearest health facility for medical attention. Using malaria parasite prevalence in children aged 2 to less than 10 years old, states that showed a parasite prevalence of less than $10 \%$ are considered as malaria hypo-endemic and those with a prevalence of $10 \%$ to less than $50 \%$ are considered malaria meso-endemic ones [23, 24]. No state demonstrated a malaria parasite prevalence of $50 \%$ or more to be classified as hyper-endemic. Wealth index was generated to provide a proxy comparable indicator of the household wealth status. The wealth index was calculated using principal component analysis (PCA) based on ownership of durable goods, household living condition, and level of household head education [25].
Variables included in PCA were restructured and recoded into multiple binary variables $(0=$ no/not present, and $1=$ yes/ present). Based on the predicted wealth index, households were ranked and disaggregated into 5 equal quintiles, with the lowest wealth quintile stands for the poorest class of the population and the highest stands for the richest.

\section{Statistical analysis}

The dependent variable in this study is the anaemia as per the definition described above. Independent variables included pregnancy status, age, type of residency, education level, wealth status, sanitation facility, water source, listening to radio (as a channel for health education), having health insurance, having malaria infection, and the level of malaria endemicity.

The analysis was done using SPSS 21. Descriptive analyses were done to describe the data and to demonstrate prevalence among PW, NPW and WRA. Mean haemoglobin level and standard deviation (SD) were generated and compared between PW and NPW and within anaemic sub-groups using T-test and ANOVA. Chi squire test was used to assess statistical differences in categorical data and T-test for continuous data. Then, multivariable analysis was done to examine the association between independent variables and anaemia (the outcome) as well as the strength of the association. Only independent variables that demonstrate a statistically significant effect on anaemia and/or on mean haemoglobin level in the bivariate analysis were further taken for the multivariable analysis. The logistic regression model was built based on a backward (likelihood Ratio) stepwise method. Original haemoglobin level variable was used to check for the absence of multicollinearity among independent variables. A variable that showed no statistical significance at $p<0.05$ was not selected to be entered in the model. Odds Ratios with its 95\% confidence intervals $(95 \% \mathrm{CI})$ and $\mathrm{P}$. values were reported. P. value of less than 0.05 was considered significant.

\section{Results}

In this survey, a total of 4271 WRA were examined for their haemoglobin level. Of them, 1385 (32.4\%) were in urban areas, $2654(62.1 \%)$ were in rural areas and 232 (5.4\%) were in camps. The PW involved in the study were 105 in urban areas, 295 in rural areas and 24 in camps giving a total of 421 (9.9\%) PW. The mean (SD) of the age among PW was 27.1 (6.6) and it was 28.3 (9.0) years in NPW $(p<0.001)$.

\section{Anaemia prevalence}

The overall prevalence of anaemia in WRA was $35.6 \%$, with a prevalence of 36.1 and $35.5 \%$ in PW and NPW, respectively. The mean (SD) haemoglobin level was 
113.9 (16.3) g/L and 123.2 (15.7) g/L in PW and NPW, respectively. Table 1 below shows the prevalence of anaemia, average haemoglobin levels, and prevalence of severe anaemia, by pregnancy status, between states and among camps, rural and urban residents. Anaemia in pregnancy is a severe public health problem in Khartoum, Kassala, South Kordofan, White Nile, West Kordofan, and South Darfur states and it is only a mild health problem in North Darfur State. On the other hand, anaemia in NPW was a severe health problem in Central Darfur, Kassala, Northern, and Khartoum states.

Based on this study anaemia is classified as severe public health problem in both PW and NPW residents in camps (PW: 41.7\%, NPW: 45.7\%) compared to rural (PW: 38.0\%, NPW: 34.3\%) and urban (PW: 29.5\%, NPW: $36.0 \%)$ residents (Table 1$)$. This variation in prevalence is only statistically significant in NPW $(p=0.004)$ but not PW $(p=0.252)$.

\section{Determinants of anaemia in pregnant women}

There were no significant statistical differences in the type of place of residence, level of education, economic status, sanitation facility used, source of drinking water, listening to the radio, having health insurance, or variations in the level of malaria endemicity between anaemic PW and non-anaemic PW according to findings of the bivariate analysis. There was a higher prevalence of anaemia (69.6\%) with malaria-infected PW compared to non-infected PW $(p=0.001)$. The mean of the haemoglobin level in PW was significantly lower in Camps residents (109.2 g/L (SD 23.1); $p=0.018)$, and in women using unsafe sources of drinking water $(113.3 \mathrm{~g} / \mathrm{L}$ (SD16.7); $p=0.044$ for open source), and in women with malaria infection $(100.8 \mathrm{~g} / \mathrm{L}(\mathrm{SD} 18.9) p<0.001)$ (Tables 1 and 2). The final model of the regression analysis has identified that only malaria infection is associated with anaemia in pregnancy (adjusted odds ratio $(\mathrm{aOR})$ 4.100; 95\%CI: $1.523-11.039 ; p=0.005)$.

\section{Determinants of anaemia in non-pregnant women}

There were no significant statistical differences between anaemic and non-anaemic NPW's age, level of education, source of drinking water, listening to the radio, having health insurance and level of malaria endemicity as revealed by the bivariate analysis. However, anaemia in NPW was found to be associated with the type of place of residence (higher prevalence in camps residents (45.7\%); $p=0.004)$, wealth index (higher prevalence among the poorest (42.1\%); $p=0.008)$, type of sanitation facility (higher prevalence among those practising open defecation (39.2\%); $p=0.011)$, and malaria infection (higher prevalence among NPW with a positive malaria test $61.0 \% ; p<0.001)$. Compared to this, haemoglobin level in NPW was found to be associated with the type of place of residence (lower levels in camps residents $(121.0 \mathrm{~g} / \mathrm{L}(\mathrm{SD} 18.3)) ; p=0.023)$, and with malaria infection (lower level in NPW with positive malaria test $(115.7 \mathrm{~g} / \mathrm{L}(\mathrm{SD} 13.6)) ; p<0.001)$ (Tables 1 and 2). The multivariable logistic regression final model revealed an association between anaemia in NPW and type of place of residence $(p=0.016)$, type of sanitation facility $(p=$ $0.005)$, and malaria infection $(\mathrm{p}<0.001)$ (Table 3). Anaemia odds were higher in camps NPW by almost $50 \%$ compared rural residents (aOR 1.499; 95\%CI 1.115-2.017; P 0.007) while there was no statistically significant difference in odds of urban residents compared to rural residents (aOR 1.134; 95\%CI 0.965-1.333; P 0.126). Despite that the model demonstrated an overall association between anaemia in NPW and type of sanitation facility used, there was no statistical significant difference in the odds of those using unsafe sanitation facility (aOR 0.854; 95\%CI 0.714-1.022; P 0.085) or those with no sanitation facility (open defecation) (aOR 1.122; 95\%CI 0.897-1.404; $P$ 0.313) when compared to those who use safe sanitation facilities. The odds of anaemia in NPW infected with malaria was more than 1.7 times higher than in non-infected women (aOR 2.776; 95\%CI 1.889-4.080; $P<0.001$ ).

\section{Determinants of anaemia in women in reproductive age}

When anaemia status was combined in PW and NPW, the univariate analysis showed no significant statistical differences between anaemia in WRA and age, level of education, source of drinking water, listening to the radio, having health insurance, and level of malaria endemicity. A higher prevalence of anaemia was observed in WRA in camps residents (45.3\%; $p=0.006)$, among the poorest $(42.3 \% ; p=$ 0.003), among those who were practising open defecation $(38.7 \% ; p=0.017)$, and among those with malaria infection $(62.4 \% ; p<0.001)$ (Tables 1 and 2 ). The logistic regression final model showed that anaemia in WRA was associated with the type of place of residence $(p=0.033)$, wealth index $(p=0.010)$, and malaria infection $(\mathrm{p}=0.003)$. Pregnancy status was not found to have an association with anaemia in WRA $(p=0.916)$ (Table 4). Odds of anaemia in WRA resident in camps were higher (aOR 1.397; 95\%CI 1.0481.863; P 0.023) compared to Rural WRA, but the association was not significant for urban residents (aOR 1.095; 95\%CI 0.931-1.289; P 0.274). For the economic class of WRA expressed as the wealth index, the odds of anaemia in the poorest women was increased (aOR 1.436; 95\%CI 1.065-1.936; P 0.018) when compared to the wealthiest group. The odds of anaemia in WRA that have malaria infection was higher by 1.9 times (OR 2.885; 95\%CI 2.021-4.119; $p<0.001$ ) compared to those with non-malaria infection. 
Table 1 Anaemia prevalence and mean haemoglobin level in women of reproductive age by pregnancy status, place of residence, and type of place of residence, Sudan, 2016

\begin{tabular}{|c|c|c|c|c|c|c|c|c|c|c|}
\hline \multicolumn{11}{|c|}{ Anaemia prevalence and mean haemoglobin level } \\
\hline \multirow[t]{2}{*}{ Variables } & & \multicolumn{3}{|c|}{ Pregnant women } & \multicolumn{3}{|c|}{ Non-pregnant women } & \multicolumn{3}{|c|}{$\begin{array}{l}\text { Women in reproductive age } \\
\text { (pregnant and non-pregnant } \\
\text { women combined) }\end{array}$} \\
\hline & & $\begin{array}{l}\text { Anaemia } \\
\text { prevalence }\end{array}$ & $\begin{array}{l}\text { Severe } \\
\text { anaemia } \\
\text { prevalence }\end{array}$ & $\begin{array}{l}\text { Total number } \\
\text { Average } \\
\text { Haemoglobin } \\
\text { level (g/L (SD)) }\end{array}$ & $\begin{array}{l}\text { Anaemia } \\
\text { prevalence }\end{array}$ & $\begin{array}{l}\text { Severe } \\
\text { anaemia } \\
\text { prevalence }\end{array}$ & $\begin{array}{l}\text { Total number } \\
\text { Average } \\
\text { Haemoglobin } \\
\text { level (g/L (SD)) }\end{array}$ & $\begin{array}{l}\text { Anaemia } \\
\text { prevalence }\end{array}$ & $\begin{array}{l}\text { Severe } \\
\text { anaemia } \\
\text { prevalence }\end{array}$ & $\begin{array}{l}\text { Total } \\
\text { number }\end{array}$ \\
\hline \multirow[t]{2}{*}{ SUDAN } & $\mathrm{n}$ & 152 & 5 & 421 & 1367 & 45 & 3850 & 1519 & 50 & 4271 \\
\hline & $\%$ & 36.1 & 1.2 & $113.9(16.3)$ & 35.5 & 1.2 & $123.2(15.7)$ & 35.6 & 1.2 & - \\
\hline \multicolumn{11}{|c|}{ Place of residence (State) } \\
\hline \multirow[t]{2}{*}{ Northern } & $\mathrm{n}$ & 5 & 0 & 17 & 97 & 1 & 220 & 102 & 1 & 237 \\
\hline & $\%$ & 29.4 & 0.0 & $113.7(12.2)$ & 44.1 & 0.5 & $119.3(14.2)$ & 43.0 & 0.4 & - \\
\hline \multirow[t]{2}{*}{ River Nile } & $\mathrm{n}$ & 5 & 0 & 22 & 79 & 0 & 286 & 84 & 0 & 308 \\
\hline & $\%$ & 22.7 & 0.0 & $119.5(12.2)$ & 27.6 & 0.0 & $125.8(13.3)$ & 27.3 & 0.0 & - \\
\hline \multirow[t]{2}{*}{ Red Sea } & $\mathrm{n}$ & 4 & 0 & 18 & 71 & 1 & 187 & 75 & 1 & 205 \\
\hline & $\%$ & 22.2 & 0.0 & $112.4(8.3)$ & 38.0 & 0.5 & $121.4(13.8)$ & 36.6 & 0.5 & - \\
\hline \multirow[t]{2}{*}{ Kassala } & $\mathrm{n}$ & 24 & 1 & 44 & 136 & 8 & 279 & 160 & 9 & 323 \\
\hline & $\%$ & 54.5 & 2.3 & $110.1(17.1)$ & 48.7 & 2.9 & $117.7(17.0)$ & 49.5 & 2.8 & - \\
\hline \multirow[t]{2}{*}{ Gedarif } & $\mathrm{n}$ & 6 & 0 & 28 & 67 & 5 & 291 & 73 & 5 & 319 \\
\hline & $\%$ & 21.4 & 0.0 & $120.8(25.6)$ & 23.0 & 1.7 & 127.7 (15.3) & 22.9 & 1.6 & - \\
\hline \multirow[t]{2}{*}{ Khartoum } & $\mathrm{n}$ & 18 & 0 & 31 & 127 & 5 & 304 & 145 & 5 & 335 \\
\hline & $\%$ & 58.1 & 0.0 & $108.9(16.0)$ & 41.8 & 1.6 & $120.4(16.2)$ & 43.3 & 1.5 & - \\
\hline \multirow[t]{2}{*}{ Gezira } & $\mathrm{n}$ & 7 & 0 & 26 & 103 & 2 & 295 & 110 & 2 & 321 \\
\hline & $\%$ & 26.9 & 0.0 & $117.5(12.5)$ & 34.9 & 0.7 & $123.6(13.0)$ & 34.3 & 6 & - \\
\hline \multirow[t]{2}{*}{ White Nile } & $n$ & 9 & 0 & 20 & 82 & 5 & 232 & 91 & 5 & 252 \\
\hline & $\%$ & 45.0 & 0.0 & $113.1(13.7)$ & 35.3 & 2.2 & $123.0(15.9)$ & 36.1 & 2.0 & - \\
\hline \multirow[t]{2}{*}{ Sinnar } & $\mathrm{n}$ & 6 & 0 & 17 & 96 & 2 & 255 & 102 & 2 & 272 \\
\hline & $\%$ & 35.3 & 0.0 & $110.0(13.3)$ & 37.6 & 0.8 & $122.3(14.8)$ & 37.5 & 0.7 & - \\
\hline \multirow[t]{2}{*}{ Blue Nile } & $\mathrm{n}$ & 17 & 0 & 45 & 56 & 0 & 207 & 73 & 0 & 252 \\
\hline & $\%$ & 37.8 & 0.0 & $114.2(18.3)$ & 27.1 & 0.0 & $124.3(12.8)$ & 29.0 & 0.0 & - \\
\hline \multirow{2}{*}{$\begin{array}{l}\text { North } \\
\text { Kordofan }\end{array}$} & $\mathrm{n}$ & 6 & 0 & 19 & 74 & 1 & 230 & 80 & 1 & 249 \\
\hline & $\%$ & 31.6 & 0.0 & $113.3(16.8)$ & 32.2 & 0.4 & $124.0(14.5)$ & 32.1 & 0.4 & - \\
\hline \multirow{2}{*}{$\begin{array}{l}\text { South } \\
\text { Kordofan }\end{array}$} & $\mathrm{n}$ & 8 & 0 & 15 & 38 & 0 & 142 & 46 & 0 & 157 \\
\hline & $\%$ & 53.3 & 0.0 & $113.1(18.1)$ & 26.8 & 0.0 & $127.7(14.4)$ & 29.3 & 0.0 & - \\
\hline \multirow[t]{2}{*}{ West Kordofan } & $\mathrm{n}$ & 4 & 0 & 9 & 30 & 1 & 95 & 34 & 1 & 104 \\
\hline & $\%$ & 44.4 & 0.0 & $112.1(14.6)$ & 31.6 & 1.1 & $125.7(18.5)$ & 32.7 & 1.0 & - \\
\hline \multirow[t]{2}{*}{ North Darfur } & $\mathrm{n}$ & 5 & 1 & 27 & 74 & 0 & 213 & 79 & 1 & 240 \\
\hline & $\%$ & 18.5 & 3.7 & $117.7(17.3)$ & 34.7 & 0.0 & $125.6(15.7)$ & 32.9 & 0.4 & - \\
\hline \multirow[t]{2}{*}{ West Darfur } & $n$ & 7 & 0 & 23 & 39 & 2 & 149 & 46 & 2 & 172 \\
\hline & $\%$ & 30.4 & 0.0 & $118.0(15.6)$ & 26.2 & 1.3 & $127.1(15.7)$ & 26.7 & 1.2 & - \\
\hline \multirow[t]{2}{*}{ South Darfur } & $\mathrm{n}$ & 10 & 2 & 24 & 87 & 4 & 224 & 97 & 6 & 248 \\
\hline & $\%$ & 41.7 & 8.3 & $109.8(23.2)$ & 38.8 & 1.8 & 124.5 (18.4) & 39.1 & 2.4 & - \\
\hline Central Darfur & $n$ & 8 & 1 & 21 & 84 & 5 & 163 & 92 & 6 & 184 \\
\hline & $\%$ & 38.1 & 4.8 & $111.8(21.2)$ & 51.5 & 3.1 & $118.0(16.8)$ & 50.0 & 3.3 & - \\
\hline East Darfur & $\mathrm{n}$ & 3 & 0 & 15 & 27 & 3 & 78 & 30 & 3 & 93 \\
\hline
\end{tabular}


Table 1 Anaemia prevalence and mean haemoglobin level in women of reproductive age by pregnancy status, place of residence, and type of place of residence, Sudan, 2016 (Continued)

\begin{tabular}{|c|c|c|c|c|c|c|c|c|c|c|}
\hline \multicolumn{11}{|c|}{ Anaemia prevalence and mean haemoglobin level } \\
\hline \multirow[t]{3}{*}{ Variables } & & \multicolumn{3}{|c|}{ Pregnant women } & \multicolumn{3}{|c|}{ Non-pregnant women } & \multicolumn{3}{|c|}{$\begin{array}{l}\text { Women in reproductive age } \\
\text { (pregnant and non-pregnant } \\
\text { women combined) }\end{array}$} \\
\hline & & $\begin{array}{l}\text { Anaemia } \\
\text { prevalence }\end{array}$ & $\begin{array}{l}\text { Severe } \\
\text { anaemia } \\
\text { prevalence }\end{array}$ & $\begin{array}{l}\text { Total number } \\
\text { Average } \\
\text { Haemoglobin } \\
\text { level (g/L (SD)) }\end{array}$ & $\begin{array}{l}\text { Anaemia } \\
\text { prevalence }\end{array}$ & $\begin{array}{l}\text { Severe } \\
\text { anaemia } \\
\text { prevalence }\end{array}$ & $\begin{array}{l}\text { Total number } \\
\text { Average } \\
\text { Haemoglobin } \\
\text { level (g/L (SD)) }\end{array}$ & $\begin{array}{l}\text { Anaemia } \\
\text { prevalence }\end{array}$ & $\begin{array}{l}\text { Severe } \\
\text { anaemia } \\
\text { prevalence }\end{array}$ & $\begin{array}{l}\text { Total } \\
\text { number }\end{array}$ \\
\hline & $\%$ & 20.0 & 0.0 & $122.2(15.0)$ & 34.6 & 3.8 & $124.1(23.8)$ & 32.3 & 3.2 & - \\
\hline p. value & & $0.033^{*}$ & 0.371 & 0.199 & $<0.001^{*}$ & $0.007^{*}$ & $<0.001^{*}$ & $<0.001^{*}$ & $0.003^{*}$ & - \\
\hline \multicolumn{11}{|c|}{ Type of place of residence (area classification) } \\
\hline \multirow{2}{*}{$\begin{array}{l}\text { IDPs/Refugees } \\
\text { Camps }\end{array}$} & $\mathrm{n}$ & 10 & 2 & 24 & 95 & 6 & 208 & 105 & 8 & 232 \\
\hline & $\%$ & 41.7 & 8.3 & $109.2(23.1)$ & 45.7 & 2.9 & $121.0(18.3)$ & 45.3 & 3.4 & - \\
\hline \multirow[t]{2}{*}{ Urban } & $n$ & 31 & 1 & 105 & 461 & 18 & 1280 & 492 & 19 & 1385 \\
\hline & $\%$ & 29.5 & 1.0 & 118.0 (19.8) & 36.0 & 1.4 & $123.2(16.3)$ & 35.5 & 1.4 & - \\
\hline \multirow[t]{2}{*}{ Rural } & $\mathrm{n}$ & 111 & 2 & 292 & 811 & 21 & 2362 & 922 & 23 & 2654 \\
\hline & $\%$ & 38.0 & 0.7 & $113.2(15.5)$ & 34.3 & 0.9 & $123.5(15.2)$ & 34.7 & 0.9 & - \\
\hline p. value & & 0.252 & $0.004^{*}$ & $0.018^{*}$ & $0.004^{*}$ & $0.023^{*}$ & 0.082 & $0.006^{*}$ & $0.001^{*}$ & - \\
\hline
\end{tabular}

$p$. value was calculated based on $x^{2}$ test for categorical data (anaemia prevalence) and with t-test for continuous data (average haemoglobin level) $p$. values with statistical significance $(p<0.05)$ is denoted with *

\section{Discussion}

Anaemia in WRA is a worldwide health problem. This study aimed to measure the prevalence of anaemia in WRA in Sudan and to identify its determinants. Findings of this study demonstrated a high level of anaemia prevalence in the country and sub-country. Estimation for Sudan, as cited by the WHO for the year 2011, showed anaemia prevalence of 25 and $31 \%$ with a mean haemoglobin level of $116 \mathrm{~g} / \mathrm{L}$ and $126 \mathrm{~g} / \mathrm{L}$ for PW and NPW respectively $[1,2]$. Our results show slightly higher levels of anaemia compared to previous WHO 2011 estimates for Sudan. Result of our study may play a role in validating country figures in the future. Both the WHO country estimates and our study values classified the problem of anaemia in Sudan to a moderate public health problem. On the other hand, this study showed a lower prevalence of anaemia among PW compared to an overall estimate of $53 \%$ generated by a systematic review of published research from Sudan [26]. This variation may be because most of the studies included in the systematic review were health facility-based compared to this population-based study. Based on the results of this study, the trend of anaemia in Sudan in WRA is markedly lower (35.6\%) compared to six states average population survey of $47.8 \%$ performed in 1995 [27]. It is hard to conclude the trend of anaemia in Sudan over time based on these three examples discussed above. Differences in anaemia prevalence may be due to variations in the method of estimation, targeted population, and sample size. However, we feel that our study provides valid insight into population values among women in reproductive age in Sudan, as a result of our sampling and measurement methodologies. The situation in Sudan is not different from many countries in the region or outside of the region. For example, the prevalence of anaemia in $\mathrm{PW}$ is $39.8 \%$ in China [5]. In Ethiopia, the prevalence of anaemia in WRA was estimated at 23\% [28]. Another good performing African country, Rwanda showed a prevalence of anaemia in WRA of $19.2 \%$ [2, 29]. Despite this low estimate in Rwanda and the noticeable improvement in maternal health services, the actual situation was showing an increasing trend in anaemia prevalence from a previous level of $17 \%$ in 2010 with huge variations at subnational level [29]. Both Ethiopia and Rwanda figures are away from a prevalence of $35.6 \%$ in this study. Despite the low number of cases identified as severe anaemia in this study, the overall prevalence does not look different from the WHO estimation for the country and the regional office figure $[1,2]$.

Subnational variation in anaemia prevalence is documented in many countries [29-32]. This rings the bell for the need to directing available resources to communities in high need as well as to design interventions at local levels based on the gaps and needs. A quite high number of states, in this study, were classified in the category of severe public health problem for anaemia in PW and NPW which should receive high attention and rapid actions. It is noticed in this study that anaemia prevalence in PW is markedly higher than that in NPW in many states and the situation is opposite in many 
Table 2 Factors affecting anaemia prevalence and mean haemoglobin level in women of reproductive age, Sudan, 2016

\begin{tabular}{|c|c|c|c|c|c|c|c|}
\hline \multirow[t]{3}{*}{ Variables } & & \multicolumn{2}{|c|}{ Pregnant women } & \multicolumn{2}{|c|}{ Non-pregnant women } & \multicolumn{2}{|c|}{$\begin{array}{l}\text { Women in reproductive age } \\
\text { (pregnant and non-pregnant } \\
\text { women combined) }\end{array}$} \\
\hline & & \multirow{2}{*}{$\begin{array}{l}\text { Anaemia } \\
\text { prevalence }\end{array}$} & \multirow{2}{*}{$\begin{array}{l}\text { Total number } \\
\text { Average Haemoglobin } \\
\text { level (g/L (SD)) }\end{array}$} & \multirow{2}{*}{$\begin{array}{l}\text { Anaemia } \\
\text { prevalence }\end{array}$} & \multirow{2}{*}{$\begin{array}{l}\text { Total number } \\
\text { Average Haemoglobin } \\
\text { level (g/L (SD)) }\end{array}$} & \multirow{2}{*}{$\begin{array}{l}\text { Anaemia } \\
\text { prevalence }\end{array}$} & \multirow{2}{*}{$\begin{array}{l}\text { Total } \\
\text { number }\end{array}$} \\
\hline & & & & & & & \\
\hline \multicolumn{8}{|l|}{ Level of education } \\
\hline \multirow[t]{2}{*}{ No formal education } & $\mathrm{n}$ & 60 & 157 & 400 & 1047 & 460 & 1204 \\
\hline & $\%$ & 38.2 & $114.6(18.3)$ & 38.2 & $122.4(16.0)$ & 38.2 & - \\
\hline \multirow{2}{*}{$\begin{array}{l}\text { Primary/religious } \\
\text { education }\end{array}$} & $\mathrm{n}$ & 67 & 176 & 537 & 1587 & 604 & 1763 \\
\hline & $\%$ & 38.1 & $112.8(18.0)$ & 33.8 & $123.7(15.1)$ & 34.3 & - \\
\hline \multirow[t]{2}{*}{ Secondary education } & $\mathrm{n}$ & 15 & 53 & 259 & 764 & 274 & 817 \\
\hline & $\%$ & 28.3 & $116.9(12.0)$ & 33.9 & $123.8(16.6)$ & 33.5 & - \\
\hline \multirow{2}{*}{$\begin{array}{l}\text { Above secondary } \\
\text { education }\end{array}$} & $\mathrm{n}$ & 10 & 35 & 171 & 452 & 181 & 487 \\
\hline & $\%$ & 28.6 & $115.8(14.7)$ & 37.8 & $122.6(16.0)$ & 37.2 & - \\
\hline p. value & & 0.414 & 0.407 & 0.066 & 0.118 & 0.072 & - \\
\hline \multicolumn{8}{|l|}{ Wealth index } \\
\hline \multirow[t]{2}{*}{ Wealthiest } & $\mathrm{n}$ & 21 & 76 & 384 & 1085 & 405 & 1161 \\
\hline & $\%$ & $27.60 \%$ & $117.8(17.3)$ & $35.40 \%$ & $122.9(15.1)$ & $35.50 \%$ & - \\
\hline \multirow[t]{2}{*}{ High } & $\mathrm{n}$ & 33 & 99 & 336 & 1008 & 369 & 1107 \\
\hline & $\%$ & $33.30 \%$ & $115.7(19.0)$ & $33.30 \%$ & $123.8(15.5)$ & $33.30 \%$ & - \\
\hline \multirow[t]{2}{*}{ Middle } & $\mathrm{n}$ & 29 & 81 & 221 & 652 & 250 & 733 \\
\hline & $\%$ & $35.80 \%$ & $113.6(16.1)$ & $33.90 \%$ & $123.9(16.7)$ & $34.10 \%$ & - \\
\hline \multirow[t]{2}{*}{ Low } & $n$ & 33 & 83 & 186 & 535 & 219 & 618 \\
\hline & $\%$ & $39.80 \%$ & $112.7(15.6)$ & $34.80 \%$ & $122.8(15.8)$ & $35.40 \%$ & - \\
\hline \multirow[t]{2}{*}{ Poorest } & $\mathrm{n}$ & 36 & 82 & 240 & 570 & 276 & 652 \\
\hline & $\%$ & $43.90 \%$ & $111.2(20.4)$ & $42.10 \%$ & $122.5(16.1)$ & $42.30 \%$ & - \\
\hline p. value & & 0.254 & 0.117 & $0.008^{*}$ & 0.324 & $0.003^{*}$ & - \\
\hline \multicolumn{8}{|l|}{ Sanitation type } \\
\hline \multirow[t]{2}{*}{ Safe sanitation } & $\mathrm{n}$ & 24 & 59 & 298 & 800 & 322 & 859 \\
\hline & $\%$ & 40.7 & $114.3(14.7)$ & 37.3 & $122.4(15.8)$ & 37.5 & - \\
\hline \multirow[t]{2}{*}{ Unsafe sanitation } & $n$ & 82 & 226 & 718 & 2128 & 800 & 2354 \\
\hline & $\%$ & 36.3 & $113.9(17.8)$ & 33.7 & $123.6(15.7)$ & 34 & - \\
\hline Open defecation & $n$ & 44 & 125 & 339 & 864 & 383 & 989 \\
\hline & $\%$ & 35.2 & $114.5(17.9)$ & 39.2 & $122.8(15.7)$ & 38.7 & - \\
\hline p. value & & 0.764 & 0.954 & $0.011^{*}$ & 0.145 & $0.017^{*}$ & - \\
\hline Source of drinking wate & & & & & & & \\
\hline Piped to the house & $n$ & 13 & 55 & 286 & 786 & 299 & 841 \\
\hline or bottled water & $\%$ & 23.6 & $119.6(14.6)$ & 36.4 & $122.7(15.4)$ & 35.6 & - \\
\hline Piped to public area & $\mathrm{n}$ & 50 & 131 & 452 & 1309 & 502 & 1440 \\
\hline & $\%$ & 38.2 & $113.4(18.9)$ & 34.5 & $123.3(15.5)$ & 34.9 & - \\
\hline Open source & $\mathrm{n}$ & 81 & 212 & 588 & 1634 & 669 & 1846 \\
\hline & $\%$ & 38.2 & $113.3(16.7)$ & 36 & $123.5(16.0)$ & 36.2 & - \\
\hline p. value & & 0.114 & $0.044^{*}$ & 0.616 & 0.487 & 0.714 & - \\
\hline Frequently listen to the & adio & & & & & & \\
\hline Yes & $n$ & 49 & 117 & 378 & 1105 & 427 & 1222 \\
\hline
\end{tabular}


Table 2 Factors affecting anaemia prevalence and mean haemoglobin level in women of reproductive age, Sudan, 2016 (Continued)

\begin{tabular}{|c|c|c|c|c|c|c|c|}
\hline \multirow[t]{3}{*}{ Variables } & & \multicolumn{2}{|c|}{ Pregnant women } & \multicolumn{2}{|c|}{ Non-pregnant women } & \multicolumn{2}{|c|}{$\begin{array}{l}\text { Women in reproductive age } \\
\text { (pregnant and non-pregnant } \\
\text { women combined) }\end{array}$} \\
\hline & & \multirow{2}{*}{$\begin{array}{l}\text { Anaemia } \\
\text { prevalence }\end{array}$} & \multirow{2}{*}{$\begin{array}{l}\text { Total number } \\
\text { Average Haemoglobin } \\
\text { level (g/L (SD)) }\end{array}$} & \multirow{2}{*}{$\begin{array}{l}\text { Anaemia } \\
\text { prevalence }\end{array}$} & \multirow{2}{*}{$\begin{array}{l}\text { Total number } \\
\text { Average Haemoglobin } \\
\text { level (g/L (SD)) }\end{array}$} & \multirow{2}{*}{$\begin{array}{l}\text { Anaemia } \\
\text { prevalence }\end{array}$} & \multirow{2}{*}{$\begin{array}{l}\text { Total } \\
\text { number }\end{array}$} \\
\hline & & & & & & & \\
\hline \multirow{3}{*}{ No } & $\%$ & 41.9 & $114.3(20.0)$ & 34.2 & $123.7(15.4)$ & 34.9 & - \\
\hline & $\mathrm{n}$ & 103 & 301 & 986 & 2734 & 1089 & 3035 \\
\hline & $\%$ & 34.2 & $114.1(16.1)$ & 36.1 & $123.1(15.9)$ & 35.9 & - \\
\hline p. value & & 0.147 & 0.884 & 0.28 & 0.282 & 0.572 & - \\
\hline \multicolumn{8}{|l|}{ Have health insurance } \\
\hline \multirow[t]{2}{*}{ Yes } & $\mathrm{n}$ & 39 & 129 & 484 & 1333 & 523 & 1462 \\
\hline & $\%$ & 30.2 & $116.2(14.4)$ & 36.3 & $123.0(16.9)$ & 35.8 & - \\
\hline \multirow[t]{2}{*}{ No } & $\mathrm{n}$ & 113 & 292 & 883 & 2517 & 996 & 2809 \\
\hline & $\%$ & 38.7 & $113.3(18.3)$ & 35.1 & $123.4(15.8)$ & 35.5 & - \\
\hline p. value & & 0.1 & 0.114 & 0.457 & 0.516 & 0.84 & - \\
\hline \multicolumn{8}{|c|}{ Malaria infection (parasitaemia) } \\
\hline \multirow[t]{2}{*}{ Positive } & $\mathrm{n}$ & 16 & 23 & 72 & 118 & 88 & 141 \\
\hline & $\%$ & 69.6 & $100.8(18.9)$ & 61.0 & $115.7(13.6)$ & 62.4 & - \\
\hline \multirow[t]{2}{*}{ Negative } & $\mathrm{n}$ & 136 & 397 & 1292 & 3722 & 1428 & 4119 \\
\hline & $\%$ & 34.3 & $114.9(16.8)$ & 34.7 & $123.5(15.7)$ & 34.7 & - \\
\hline p. value & & $0.001^{*}$ & $<0.001^{*}$ & $<0.001^{*}$ & $<0.001^{*}$ & $<0.001^{*}$ & - \\
\hline \multicolumn{8}{|c|}{ Level of malaria endemicity } \\
\hline \multirow{2}{*}{$\begin{array}{l}\text { Meso-endemic } \\
\text { (PR2-10 = 10-<50\%) }\end{array}$} & $\mathrm{n}$ & 33 & 81 & 178 & 512 & 211 & 593 \\
\hline & $\%$ & 40.7 & $113.4(18.8)$ & 34.8 & $123.2(15.1)$ & 35.6 & - \\
\hline \multirow{2}{*}{$\begin{array}{l}\text { Hypo-endemic } \\
\text { (PR2-10 =<10\%) }\end{array}$} & $\mathrm{n}$ & 119 & 340 & 1189 & 3338 & 1308 & 3678 \\
\hline & $\%$ & 35.0 & 114.4 (16.9) & 35.6 & $123.2(15.8)$ & 35.6 & - \\
\hline p. value & & 0.334 & 0.633 & 0.707 & 0.977 & 0.993 & - \\
\hline
\end{tabular}

$p$. value was calculated based on $x^{2}$ test for categorical data (anaemia prevalence) and with t-test for continuous data (average haemoglobin level) $p$. values with statistical significance $(p<0.05)$ is denoted with *

others. Further work may be needed to explore why this is the case in order to inform future interventions.

NPW and WRA in camps tended to be more prone to have anaemia compared to rural women as per the findings of this study. The special circumstances facing population living in camps (both IDPs and refugees) affecting their whole life including their health status. This study classified PW and NPW living in camps as affected by a severe public health problem. It is also noticed that NPW in rural areas look like as being less affected by anaemia compared to urban and camp women. Severe anaemia is seen with high prevalence both among PW and NPW in camps compared to the rural and urban population. Overall results of this study stand at giving more priority for PW and NPW at camps in regards to anti anaemia interventions. Many studies documented the high burden of anaemia in IDPs and Refugees camps [33-37].
Our findings of the association between malaria and anaemia were reported by several previous studies [29, 38]. Malaria has complicated pathophysiology in causing anaemia. Anaemia in malaria is mainly due to the removal of unparasitized red blood cells by the spleen as well as the destruction of parasitised erythrocytes as part of the schizogony process. These two processes are usually accompanied by erythropoiesis dysfunction [39-41]. With the fact that anaemia develops rapidly in malaria, the second process may have little effect $[39,40]$. Immunological factors and mechanism play an important role in the development of anaemia in malaria which include innate, cellmediated and humoral immune systems as well as a nonspecific immune response $[39,40]$. The development of severe anaemia is due to the failure of the bone marrow to recover from a previous insult as a result of repeated malaria infections [39, 41]. Both parasitised and unparasitised red blood cells become less deformable in severe malaria and thus removed by the spleen [41]. Despite that 
Table 3 Regression analysis for factors associated with anaemia in non-pregnant women, Sudan, 2016

\begin{tabular}{|c|c|c|c|c|c|}
\hline \multirow[t]{2}{*}{ Variables } & \multirow[t]{2}{*}{ Frequency } & \multicolumn{2}{|l|}{ Unadjusted analysis } & \multicolumn{2}{|l|}{ Adjusted analysis } \\
\hline & & $\mathrm{COR}^{\mathrm{a}}(95 \% \mathrm{Cl})$ & $P$. value ${ }^{\ddagger}$ & $\mathrm{aOR}^{\mathrm{b}}(95 \% \mathrm{Cl})$ & p. value ${ }^{\ddagger}$ \\
\hline \multicolumn{6}{|c|}{ Type of place of residence (area classification) } \\
\hline Rural & 2291 & 1 & 0.015 & 1 & 0.016 \\
\hline Urban & 1231 & $1.135(0.958-1.346)$ & 0.144 & $1.134(0.965-1.333)$ & 0.126 \\
\hline IDP/Refugee Camps & 200 & $1.505(1.110-2.040)$ & 0.008 & $1.499(1.115-2.017)$ & 0.007 \\
\hline \multicolumn{6}{|l|}{ Wealth index } \\
\hline Wealthiest & 1052 & 1 & 0.193 & & \\
\hline High & 972 & $0.972(0.802-1.178)$ & 0.772 & & \\
\hline Middle & 627 & $0.967(0.763-1.225)$ & 0.778 & - & - \\
\hline Low & 521 & $0.936(0.714-1.227)$ & 0.632 & & \\
\hline Poorest & 550 & $1.289(0.941-1.767)$ & 0.114 & & \\
\hline \multicolumn{6}{|l|}{ Sanitation type } \\
\hline Safe sanitation facility & 773 & 1 & 0.174 & 1 & 0.005 \\
\hline Unsafe sanitation facility & 2096 & $0.860(0.713-1.038)$ & 0.116 & $0.854(0.714-1.022)$ & 0.085 \\
\hline Open defecation & 853 & $0.983(0.735-1.313)$ & 0.906 & $1.122(0.897-1.404)$ & 0.313 \\
\hline \multicolumn{6}{|c|}{ Malaria infection (parasitaemia) } \\
\hline Negative & 3608 & 1 & $<0.001$ & 1 & $<0.001$ \\
\hline Positive & 114 & $2.756(1.871-4.058)$ & $<0.001$ & $2.776(1.889-4.080)$ & $<0.001$ \\
\hline
\end{tabular}

${ }^{a}$ cOR: Crude Odd Ratio. ${ }^{b}$ aOR: Adjusted Odd Ratio

$\neq p$. values in bold reflect the overall exposure and are derived from the likelihood ratio test. p. value for variables with multiple exposure level are reported from the Wald test

Goodness-of-fit test (Hosmer and Lemeshow) for the adjusted final model for non-pregnant women $X^{2} 0.210(4$ degrees of freedom; $p$. value $=0.995)$

pregnant women in moderate and high malaria transmission areas are previously immune, they tend to experience asymptomatic $P$. falciparum malaria, and hence be more prone to the pathogenesis of anaemia. Placental parasitaemia may be present in the absence of peripheral parasitaemia and thus contribute to anaemia. In such settings, the effect of $P$. falciparum infection during pregnancy is affecting first pregnancies at the most [40, 42]. In Sudan, most of the states are classified as hypo-endemic malaria areas with few as meso-endemic [43]. Results of this study did not demonstrate the relationship between anaemia in PW and the level of malaria endemicity. So, the national authority has to revise the need for using IPTp as a strategy for malaria control in areas classified as mesoendemic in Sudan. On the other hand, timely access to malaria diagnosis and prompt case management may have a superior role in reducing anaemia on top of other malaria control interventions in low to moderate malaria transmission settings.

This study did not find an association between pregnancy status and anaemia. In a systematic review involved four countries from Africa anaemia, iron deficiency, and iron deficiency anaemia prevalence were found to be lower in PW compared to WRA [44]. The same situation was seen in Europe [45]. The case in the United States (US) does not prove this. In the US, iron deficiency was found to be higher in PW compared to
NPW, but iron deficiency anaemia was found to be lower in PW compared to NPW [46].

The association between anaemia and parasitic infection is well established. Evidence showed good impact in reducing anaemia through interventions against helminths in high-risk communities [4]. This research studied the link between access to safe water and access to safe sanitation to anaemia. Safe water sources and safer sanitation facilities are considered as major interventions in reducing soil-transmitted helminths. Type of sanitation facility used was found in this study to be only associated with anaemia in NPW. However, there is no statistical difference in odds of anaemia among those using unsafe sanitation facilities or open defecation with those who have safe sanitation facilities. Access to safe water sources was found to be neither associated with anaemia in PW nor with anaemia in NPW.

In this study, the association between economic status and anaemia was found for WRA. Results show that the poorest are more affected by anaemia than the richest women. This research is supporting other findings [29]. A study in Myanmar, however, did not find an association between anaemia and wealth status [32].

Many studies showed the lack of association between anaemia in pregnancy and mothers' age and level of education $[12,13,29,32]$. Such a situation has been identified in this research among WRA including PW and 
Table 4 Regression analysis for factors associated with anaemia in women in reproductive age, Sudan, 2016

\begin{tabular}{|c|c|c|c|c|c|}
\hline \multicolumn{6}{|c|}{ Women in reproductive age (pregnant and non-pregnant women combined) } \\
\hline \multirow[t]{2}{*}{ Variables } & \multirow[t]{2}{*}{ Frequency } & \multicolumn{2}{|l|}{ Unadjusted analysis } & \multicolumn{2}{|l|}{ Adjusted analysis } \\
\hline & & $\mathrm{COR}^{\mathrm{a}}(95 \% \mathrm{Cl})$ & p. value ${ }^{\ddagger}$ & $\mathrm{aOR}^{\mathrm{b}}(95 \% \mathrm{Cl})$ & p. value \\
\hline \multicolumn{6}{|c|}{ Type of place of residence (area classification) } \\
\hline Rural & 2571 & 1 & 0.052 & 1 & 0.033 \\
\hline Urban & 1334 & $1.095(0.931-1.289)$ & 0.274 & $1.095(0.931-1.289)$ & 0.274 \\
\hline IDP/Refugee Camps & 244 & $1.398(1.048-1.863)$ & 0.022 & $1.397(1.048-1.863)$ & 0.023 \\
\hline \multicolumn{6}{|l|}{ Pregnancy status } \\
\hline Pregnant & 407 & 1 & 0.916 & - & - \\
\hline Non-pregnant & 3722 & $0.988(0.796-1.227)$ & 0.916 & & \\
\hline \multicolumn{6}{|l|}{ Wealth index } \\
\hline Wealthiest & 1126 & 1 & 0.081 & 1 & 0.010 \\
\hline High & 1070 & 0.995 (0.827-1.198) & 0.961 & $0.996(0.828-1.198)$ & 0.963 \\
\hline Middle & 702 & 1.026 (0.818-1.286) & 0.825 & $1.026(0.819-1.286)$ & 0.823 \\
\hline Low & 601 & 1.041 (0.806-1.344) & 0.760 & $1.041(0.806-1.345)$ & 0.765 \\
\hline Poorest & 630 & 1.435 (1.064-1.935) & 0.018 & $1.436(1.065-1.936)$ & 0.018 \\
\hline \multicolumn{6}{|l|}{ Sanitation type } \\
\hline Safe sanitation facility & 831 & 1 & 0.121 & & \\
\hline Unsafe sanitation facility & 2320 & $0.827(0.691-0.991)$ & 0.040 & - & - \\
\hline Open defecation & 978 & $0.850(0.645-1.120)$ & 0.249 & & \\
\hline \multicolumn{6}{|c|}{ Malaria infection (parasitaemia) } \\
\hline Negative & 3992 & 1 & 0.007 & 1 & 0.003 \\
\hline Positive & 137 & $2.883(2.019-4.117)$ & $<0.001$ & $2.885(2.021-4.119)$ & $<0.001$ \\
\hline
\end{tabular}

NPW. In Rwanda, exposure to educational channels such as reading newspapers, listening to the radio, or watching television did not show any statistical difference in the prevalence of anaemia in pregnancy compared to unexposed [29]. Listening to the radio did however not appear to affect anaemia prevalence in PW and NPW in our study. Financial hardship on communities stands as a big barrier for accessibility to health services. Health insurance as a mean for overcoming this challenge served many beneficiaries. This study did not find any statistical difference of anaemia between those with health insurance and those without, both among PW and NPW. Some barriers may however still face the population with health insurance from getting the benefit of health insurance services. Such obstacles need to be elaborated and addressed to have financial protection available for all.

This study has various strengths and limitations. Study limitations include the low frequency of severe anaemia that limits further analysis to find out its determinants. Another issue is that the level of haemoglobin/anaemia neither adjusted for smoking nor the altitude. More is that pregnancy status in this study was not validated by any test or procedure and was depending on women response. This study did not address parity, previous obstetrical complications, or screening for haemoglobinopathies, enzymopathies, haematological disorders, or chronic diseases. Neither participants' use of pica nor the use of iron or folic acid supplements were assessed in this study. The cross-sectional design of this study and the nature of the logistic regression model developed with a limited number of variables are the additional limitation of this study. One major strength of this study is that it is the first large-scale study that provided anaemia prevalence estimates for all states of the country. This will set real-life baseline estimates for monitoring progress in the fight against anaemia. Other study strengths include disaggregation of results by pregnancy status, coverage of IDPs/refugees camps population, the focus on determinants of anaemia, and presentation of results by both anaemia prevalence and haemoglobin level.

\section{Conclusions}

With the level of anaemia prevalence identified in this study, WRA in Sudan are facing a challenging health 
problem, both at national and sub-national levels. The problem is severely affecting camps residents. The study established the association between malaria infection and anaemia. With the context of Sudan, low and moderate malaria transmission was not found to affect anaemia prevalence. Thus, early diagnosis and effective treatment of malaria cases are of utmost importance in such situation.

Concerning anaemia, Sudan health authority needs to consider subnational level variations and give priority to the people most in need when designing interventions and allocating resources. Achieving progress in access to prompt and effective malaria case management is likely to have a high impact on reducing the burden of anaemia. Improving living conditions as well as reducing poverty may contribute to improving the haemoglobin level of affected communities.

\section{Abbreviations \\ aOR: Adjusted Odd ratio; GDP: Gross domestic product; IDPs: Internally displaced persons; IPTp: Intermittent presumptive treatment for pregnant women; NPW: Non-pregnant women; OR: Odd ratio; PAUs: Popular administrative units; PCA: Principal component analysis; PDA: Personal data assistant; PW: Pregnant women; RDT: Rapid diagnostic test; SD: Standard deviation; US: The United States; WHO: World Health Organization; WRA: Women in reproductive age; $95 \% \mathrm{Cl}$ : 95\% confidence interval}

\section{Acknowledgements}

The authors are acknowledging the efforts of the fieldwork team and supervisors as well as the community leaders. Special thanks to the study participants for their voluntary participation and making their data available for benefit of their communities and the world health. Authors also acknowledge the national and local government and the police, military and security officers who pave the road for the fieldwork, especially in the hard to reach areas.

\section{Authors' contributions}

KAE and EMM have designed the study. KAE, EMM, TAA, MSA, AAl, MAB, AHE, HTK, ATA, LMN, and MSA participated in the planning and implementation of the survey. MSA was responsible for data management. KAE and MSA guided the analysis and SK, IA, and EMM revised and commented on it. KAE wrote the first draft of the paper. All other authors contributed to the writing and improvement of the draft manuscript. All authors read the final version and approved it.

\section{Funding}

The malaria indicator survey, in which this study was merged, was funded by the Global Fund to Fight AIDS, TB and Malaria through the United Nation Development Programme as the principal recipient. Additional financial and logistical support for the survey was provided by the government of Sudan. Recruitment of the survey national consultant was provided by the WHOEMR and the Sudan WHO-Country offices. Fund from above mentioned funders was used for the survey design, data collection, analysis and writing of the final report of the malaria indicator survey. Funders have no role in the analysis, interpretation, or writing of this manuscript.

\section{Availability of data and materials}

The datasets used during the current study are available from the Communicable and Non-communicable diseases Control Directorates, Federal Ministry of Health, Sudan on reasonable request.

\section{Ethics approval and consent to participate}

Ethical clearance for this survey was obtained from the ethical and technical review board, directorate of health research, Sudan federal ministry of health. Written informed consent was obtained from participants after describing the objectives and procedures of the study. Participants were assured for their rights to participate/withdraw their consent.

\section{Consent for publication}

Not applicable.

\section{Competing interests}

The authors declare that they have no competing interests.

\section{Author details}

${ }^{1}$ Health Information, Monitoring and Evaluation and Evidence Department, Federal Ministry of Health, Khartoum, Sudan. ${ }^{2}$ Department of Obstetrics and Gynecology, Unaizah College of Medicine and Medical Sciences, Qassim University, Unaizah, Saudi Arabia. ${ }^{3}$ Faculty of Medicine, University of Khartoum, Khartoum, Sudan. ${ }^{4}$ Communicable and Non-Communicable Diseases Control Directorate, Federal Ministry of Health, Khartoum, Sudan. ${ }^{5}$ Directorate of Pharmacy, Federal Ministry of Health, Khartoum, Sudan. ${ }^{6}$ Directorate General of Primary Health Care, Federal Ministry of Health, Khartoum, Sudan. ${ }^{7}$ Department of Health Promotion, NUTRIM School of Nutrition and Translational Research in Metabolism, Faculty of Health, Medicine and Life Sciences, Maastricht, The Netherlands.

Received: 28 April 2020 Accepted: 13 July 2020

Published online: 17 July 2020

\section{References}

1. Stevens GA, Finucane MM, De-Regil LM, Paciorek CJ, Flaxman SR, Branca F, et al. Global, regional, and national trends in haemoglobin concentration and prevalence of total and severe anaemia in children and pregnant and non-pregnant women for 1995-2011: A systematic analysis of populationrepresentative data. Lancet Glob Heal. 2013;1:e16-25.

2. WHO. The Global Prevalence of Anaemia in 2011. Geneva: World Health Organization; 2015. www.who.int. Accessed 18 Jun 2019.

3. Janus J, Moerschel SK. Evaluation of anemia in children. Am Fam Physician. 2010;81:1462-71.

4. Bates I, McKew S, Sarkinfada F. Anaemia: a useful indicator of neglected disease burden and control. PLoS Med. 2007:4:1285-90.

5. Jin L, Yeung LF, Cogswell ME, Ye R, Berry RJ, Liu J, et al. Prevalence of anaemia among pregnant women in south-East China, 1993-2005. Public Health Nutr. 2010;13:1511-8.

6. Nair M, Choudhury MK, Choudhury SS, Kakoty SD, Sarma UC, Webster P, et al. Association between maternal anaemia and pregnancy outcomes: a cohort study in Assam, India. BMJ Glob Heal. 2016;1:e000026.

7. Ali AAA, Adam I. Anaemia and stillbirth in Kassala hospital, Eastern Sudan. J Trop Pediatr. 2011;57:62-4. https://doi.org/10.1093/tropej/fmq029.

8. Marchant T, Schellenberg JA, Nathan R, Abdulla S, Mukasa O, Mshinda H, et al. Anaemia in pregnancy and infant mortality in Tanzania. Trop Med Int Heal. 2004;9:262-6. https://doi.org/10.1046/j.1365-3156.2003.01178.x.

9. Plessow R, Arora NK, Brunner B, Tzogiou C, Eichler K, Brügger U, et al. Social costs of iron deficiency anemia in 6-59-month-old children in India. PLoS One. 2015;10:e0136581.

10. McLean E, Cogswell M, Egli I, Wojdyla D, de Benoist B. Worldwide prevalence of anaemia 1993-2005. Geneva: Switztzerland; 2008. www.who. int/vmnis.

11. WHO. WHA Global Nutrition Targets 2025: Anaemia Policy Brief. Geneva; 2014. https://www.who.int/nutrition/topics/globaltargets_anaemia_ policybrief.pdf. Accessed 28 Dec 2019.

12. Abdelgadir MA, Khalid AR, Ashmaig AL, Ibrahim ARM, Ahmed A-AM, Adam I. Epidemiology of anaemia among pregnant women in Geizera, Central Sudan. J Obstet Gynaecol (Lahore). 2012;32:42-4. https://doi.org/10.3109/ 01443615.2011.617849.

13. Adam I, Khamis AH, Elbashir MI. Prevalence and risk factors for anaemia in pregnant women of eastern Sudan. Trans R Soc Trop Med Hyg. 2005;99: 739-43. https://doi.org/10.1016/j.trstmh.2005.02.008.

14. Adam I, El-Ghazali G, Mohamedin M, Elbashir MI. Anemia in pregnant Sudanese women. Saudi Med J. 2004;25:1119-20 https://www.researchgate. net/publication/8388647

15. Abdelrahim II, Adam GK, Mohmmed AA, Salih MM, Ali NI, Elbashier MI, et al. Anaemia, folate and vitamin B12 deficiency among pregnant women in an area of unstable malaria transmission in eastern Sudan. Trans R Soc Trop Med Hyg. 2009;103:493-6. https://doi.org/10.1016/j.trstmh.2008.10.007. 
16. Federal Ministry of Health. National Nutrition Strategic Plan 2014-2025. Khartoum, Sudan: Federal Ministry of Health; 2014. http://www.sho.gov.sd/ controller/knowledge_hub.

17. The World Bank Group. Sudan Data. 2019. https://data.worldbank.org/ country/sudan. Accessed 22 Jan 2020.

18. Central Bureau of Statistics. Sudan Population Data Sheet 2018. Khartoum Sudan; 2018. http://cbs.gov.sd//resources/uploads/files/. Accessed 19 Jan 2020.

19. Federal Ministry of Health. National Health Sector Strategic Plan (20122016). Khartoum, Sudan: Federal Ministry of Health; 2011. http://www.sho. gov.sd/controller/knowledge_hub.

20. WHO. Haemoglobin concentrations for the diagnosis of anaemia and assessment of severity. Geneva; 2011. https://www.who.int/vmnis/indicators/ haemoglobin/en/. Accessed 7 Jan 2020.

21. WHO. The management of nutrition in major emergencies. Geneva: World Health Organization; 2000. https://www.who.int/nutrition/publications/ emergencies/9241545208/en/. Accessed 6 Jan 2020.

22. MAESURE Evaluation. Percent of women of reproductive age with anemia - MEASURE Evaluation https://www.measureevaluation.org/prh/rh_ indicators/womens-health/womens-nutrition/percent-of-women-ofreproductive-age-with-anemia. Accessed 28 Dec 2019.

23. Hay SI, Smith DL, Snow RW. Measuring malaria endemicity from intense to interrupted transmission. Lancet Infect Dis. 2008:8:369-78. https://doi.org/10. 1016/S1473-3099(08)70069-0.

24. WHO. WHO malaria terminology Global Malaria Programme. Geneva: World Health Organization; 2019. http://www.who.int/malaria. Accessed 15 Jan 2020.

25. Rutstein SO, Johnson K. The DHS Wealth Index. DHS Comparative Reports No. 6. Calverton, Maryland; 2004. https://dhsprogram.com/pubs/pdf/CR6/ CR6.pdf. Accessed 12 Jun 2020

26. Adam I, Ibrahim Y, Elhardello O. Prevalence, types and determinants of anemia among pregnant women in Sudan: a systematic review and metaanalysis. BMC Hematol. 2018;18:31. https://doi.org/10.1186/s12878-018-0124-1.

27. WHO. WHO Global Database on Anaemia - Sudan. Geneva, Switztzerland; 2006. https://www.who.int/vmnis/database/anaemia/countries/en/. Accessed 7 Jan 2020

28. Tadesse AW, Hemler EC, Andersen C, Passarelli S, Worku A, Sudfeld CR, et al. Anemia prevalence and etiology among women, men, and children in Ethiopia: a study protocol for a national population-based survey. BMC Public Health. 2019:19:1369. https://doi.org/10.1186/s12889-019-7647-7.

29. Hakizimana D, Nisingizwe MP, Logan J, Wong R. Identifying risk factors of anemia among women of reproductive age in Rwanda - a cross-sectional study using secondary data from the Rwanda demographic and health survey 2014/2015. BMC Public Health. 2019;19:1662.

30. Khader A, Madi H, Riccardo F, Sabatinelli G. Anaemia among pregnant Palestinian women in the occupied Palestinian territory. Public Health Nutr. 2009;12:2416-20.

31. Ahmed F. Anaemia in Bangladesh: a review of prevalence and aetiology. Public Health Nutr. 2000:3:385-93.

32. Win H, Ko M. Geographical disparities and determinants of anaemia among women of reproductive age in Myanmar: analysis of the 2015-2016 Myanmar demographic and health survey. WHO South-East Asia J Public Heal. 2018:7:107. https://doi.org/10.4103/2224-3151.239422.

33. Ajakaye OG, Ibukunoluwa MR. Prevalence and risk of malaria, anemia and malnutrition among children in IDPs camp in Edo state, Nigeria. Parasite Epidemiol Control. 2020;8:e00127. https://doi.org/10.1016/j.parepi.2019. e00127.

34. Burnham G, Lafta R, Aflouk NA, Dihaa S, Lyles E. Needs of Internally Displaced Women and Children in Baghdad, Karbala, and Kirkuk, Iraq. PLoS Curr. 2016;8. https://doi.org/10.1371/currents.dis. fefc1fc62c02ecaedec2c25910442828.

35. Oboth P, Gavamukulya Y, Barugahare BJ. Prevalence and clinical outcomes of plasmodium falciparum and intestinal parasitic infections among children in Kiryandongo refugee camp, mid-Western Uganda: a cross sectional study. BMC Infect Dis. 2019;19:295. https://doi.org/10.1186/s12879-019-3939-x.

36. Leidman E, Humphreys A, Cramer BG, Toroitich-Van Mil L, Wilkinson C, Narayan $A$, et al. Acute malnutrition and anemia among rohingya children in Kutupalong camp, Bangladesh. JAMA. 2018:319:1505-6.

37. Engidaw MT, Wassie MM, Teferra AS. Anemia and associated factors among adolescent girls living in aw-Barre refugee camp, Somali regional state,
Southeast Ethiopia. PLoS One. 2018;13:e0205381. https://doi.org/10.1371/ journal.pone.0205381.

38. Ononge S, Campbell O, Mirembe F. Haemoglobin status and predictors of anaemia among pregnant women in Mpigi, Uganda. BMC Res Notes. 2014; $7: 712$

39. Douglas NM, Anstey NM, Buffet PA, Poespoprodjo JR, Yeo TW, White NJ, et al. The anaemia of plasmodium vivax malaria. Malar J. 2012;11:135.

40. Juan Q, Machado S, Alberto T, Silvia B, Alberto M, Myriam A-H, et al. Malariarelated anaemia: a Latin American perspective. Mem Inst Oswaldo Cruz. 2011;106:91-104 http://www.scielo.br/pdf/mioc/v106s1/12.pdf. Accessed 18 Jun 2019.

41. WHO. Severe malaria. Trop Med Int Heal. 2014;19((Supp.)):7-131. https://doi. org/10.1111/tmi.12313_2.

42. WHO. World malaria report 2019. Geneva: World Health Organization; 2019. https://www.who.int/publications-detail/world-malaria-report-2019. Accessed 13 Jan 2020

43. Noor AM, ElMardi KA, Abdelgader TM, Patil AP, Amine AAA, Bakhiet S, et al. Malaria risk mapping for control in the republic of Sudan. Am J Trop Med Hyg. 2012;87:1012-21.

44. Harika R, Faber M, Samuel F, Kimiywe J, Mulugeta A, Eilander A. Micronutrient status and dietary intake of Iron, vitamin a, iodine, Folate and zinc in women of reproductive age and pregnant women in Ethiopia, Kenya, Nigeria and South Africa: a systematic review of data from 2005 to 2015. Nutrients. 2017;9:1096. https://doi.org/10.3390/nu9101096.

45. Milman N, Taylor CL, Merkel J, Brannon PM. Iron status in pregnant women and women of reproductive age in Europe. Am J Clin Nutr. 2017:106 Supplement 6:1655S-62S. https://doi.org/10.3945/ajcn.117.156000.

46. Gupta PM, Hamner HC, Suchdev PS, Flores-Ayala R, Mei Z. Iron status of toddlers, nonpregnant females, and pregnant females in the United States. Am J Clin Nutr. 2017;106 Supplement 6:1640S-6S. https://doi.org/10.3945/ ajcn.117.155978.

\section{Publisher's Note}

Springer Nature remains neutral with regard to jurisdictional claims in published maps and institutional affiliations.
Ready to submit your research? Choose BMC and benefit from:

- fast, convenient online submission

- thorough peer review by experienced researchers in your field

- rapid publication on acceptance

- support for research data, including large and complex data types

- gold Open Access which fosters wider collaboration and increased citations

- maximum visibility for your research: over $100 \mathrm{M}$ website views per year

At $\mathrm{BMC}$, research is always in progress.

Learn more biomedcentral.com/submission 